\title{
ECO-PESANTREN AS THE PANACEA FOR GLOBAL CLIMATE CHANGE: LESSONS FROM NURUL HARAMAIN NW LOMBOK ISLAMIC BOARDING SCHOOL INDONESIA
}

\author{
Abdul Quddus \\ Universitas Islam Negeri Mataram, NTB, Indonesia \\ abdul.quddus@uinmataram.ac.id
}

\begin{abstract}
This paper examined the ecological concept and its implication at Nurul Haramain NW Lombok Islamic boarding school in response to the world climate crisis. Boarding schools have the potentials to bridge the environmental conservation initiative amid the secular science phenomena. This study employed a descriptive-explorative approach using a qualitative methodology. Thus, theoretically, this study was anchored in Mary Evelyn Tucker and Vasudha Narayan's theories of eco-theology in addressing the climate crisis. The findings showed that Nurul Haramain NW Lombok Islamic boarding school had implemented a sustainable lifestyle based on the ecological values in the Al-Quran and Hadith, in which Tuan Guru as the environmental conservation foreman.
\end{abstract}

Keywords: Eco-Pesantren, Climate Change, Environmental Crisis, Educational Theology, Eco Theology

\section{INTRODUCTION}

Climate change has inevitably happened where humans are blamed for the catastrophe. There is no significant effort to manage natural resources and to change people's mindsets regarding this issue. Exploitative and consumptive behaviors are the results of the anthropocentric paradigm that placed humans as the center of the universe for years. Also, global warming is the process of global temperature extremes rise causing the rise of sea levels, dramatic weather changes, melting glaciers, early snowmelts, agricultural damages, and animal extinction (Kodra, 2007, p. 45).

Indonesia is placed as the second-fastest country undergoing deforestation with an average of 1.871 million hectares per year (2 percent) out of the remaining forest. WALHI (Wahana Lingkungan Hidup Indonesia) estimated the number of deforestation once escalated to 3,4 million hectares per year. Illegal logging caused a 40-65 trillion loss every year. Deforestation 
Quddus, A. (2020). ECO-PESANTREN AS THE PANACEA FOR GLOBAL CLIMATE CHANGE: LESSONS FROM NURUL HARAMAIN NW LOMBOK ISLAMIC BOARDING SCHOOL INDONESIA. Jurnal Tatsqif, 18 (2), 111-121. https://doi.org/10.20414/itq.v17i2.2741

and illegal logging have to lead to 673 disasters in Indonesia since 1998-2004 and more than $65 \%$ are forest mismanagements that caused floods, landslides, and forest fires. Indonesia's coastal lines and oceans are constantly disrupted. According to the World Bank, $41 \%$ of coral reefs are in the worst condition, $29 \%$ destroyed, $25 \%$ in a fairly good state, and only $5 \%$ are healthy. About 50\% of mangroves in Sulawesi have been deforested (some of which have been turned into shrimp farms). Several areas are also polluted. Indonesia's marine areas are also vulnerable to illegal fishing. This activity is carried out by more than 10 foreign countries over the last 15 years and has reduced $30-50 \%$ of the total national fishing potential each year (Alieansi Manado, 2009, p. 2).

Secular science is believed to fail in addressing these climate issues, this urged the environmental activists to endorse spiritualism as an effective solution. Evelyn believed that religion has five perfect recipes to preserve nature they are: Reference, Respect, Restrain, Redistribution, and Responsibility. Vasudha Narayan also stated that there three basic efforts to save the world based on religious beliefs, Text, Temple, and Teacher (Tucker, 2000, p. 12).

Gardner recommended environmental activist to consider religion as the climate crisis solutions. The roles of religion in the scientific context are codependency of cosmology and ecology values, moral authority, huge followers foundation, significant material resources, and community building capacity (Gadner, 2002).

From the insights above, it is clear that religion is likely to play a role in the environmental conservation. As reflected in the classic works of Islamic law (fiqh), there are main elements related to environmental preservation that discusses environmental themes. As can be read, in the classical fiqh there are chapters such as al-Tahārah (holy), al-Shaid (hunting), Ihyā' alMaut (utilizing the dead land), al-'At'imah (the law of food), al-Asyribah (the law of drink), and others. 
One of the Islamic education institutions that could potentially be a leading agent in environmental conservation is Pesantren. Pesantren is one of the elements of society that has the potential to encourage the growth of environmental conservation culture in Indonesia. This non-formal educational institution has long played a significant role not only in trying to "educate the life of the nation" and safeguard the morality of its community but also to prove to be a potential agent of social change. On the other hand, traditional Pesantren is more focused on religious subjects. The majority of Pesantren in Indonesia is a traditional boarding school and is therefore independent of formal government control (Tan, 2012).

According to Horikoshi, Tuan Guru or Kyai has a purposive role in social change, promoting elements of the outside system and causing a change in society A broad role rather than a cultural broker (Horikoshi, 1987, p. 242).

The involvement of the Kyai or Tuan Guru in addressing these climate issues is affected by two points; 1) There is a deep and high sense of societal (highly developed social sense), 2) Concerning problems on a consensus. Furthermore, through and moving on from the two potentials that these Kyai have played an active role in the existing social structures. According to Sulaiman (1998), Kyai or Tuan Guru has acted as a "pressure group" and "ruling class" at the rural level.

Ironically, in reality, pesantren, Da'i, and ulama as the spearhead of Islamic da'wah do not seem to have made the environmental crisis as an urgent material in their da'wah. It can be seen from the lack of da'wah material concerning the environmental issues, whilst compared to the narratives of religious rituals. This article is aimed to examine the ecological concept and its implication at Nurul Haramain NW Lombok Islamic boarding school in response to the world climate crisis. 


\section{METHOD}

This study employed a descriptive-explorative approach with a qualitative methodology. Qualitative study is related to the development of social phenomena issues. Arikunto (2010, p. 14). Theoretically, this study was anchored in Mary Evelyn Tucker and Vasudha Narayan's eco-theology theories of eco-theology in addressing the climate crisis. For that reason, this study explored the conceptual and practical of eco-theology in Islamic boarding schools to combat climate change.

Based on the explanation above, further study regarding this issue is intriguing and is urgent to explore. The urgency of the present study is first, the majority of Indonesians are adopting the paternalistic culture. Specifically in Lombok, this paternalistic culture mingles into Islamic culture which is marked by mosques and Islamic boarding schools. The blend of these cultures making central the Islamic boarding schools' role within the society. Second, a lack of previous studies that focused on Islamic boarding schools' role discourse in facing the climate crisis. However, Islamic boarding schools can be the foundation for grass root movements addressing this climate problem. Third, the result of this study can be adopted to develop Islamic eco-boarding schools in Indonesia.

\section{RESULT AND DISCUSSION}

Islamic eco-boarding school is defined as a sustainable school that adopts the green principle to sustain its surroundings including sustainable housing as well as their lifestyles. To preserve the school's environmental sustainability, Islamic eco-theology discourse should be done to meet the standard of environmental sustainability (Bahri, 2018, p. 45).

Eco-theology is a constructive form of theology that explains the connections of religion and nature (interrelationship of religion and nature) mainly the environment. The basic principle of eco-theology believed that 
Quddus, A. (2020). ECO-PESANTREN AS THE PANACEA FOR GLOBAL CLIMATE CHANGE: LESSONS FROM NURUL HARAMAIN NW LOMBOK ISLAMIC BOARDING SCHOOL INDONESIA. Jurnal Tatsqif, 18 (2), 111-121. https://doi.org/10.20414/itq.v17i2.2741

climate crisis is not a mere secular problem but also a false religious belief concerning lives and natures.

In the Christian beliefs eco-theology is quite clearly defined, Lynn White, stated:

What people do about their ecology depends on what they think about themselves in relation to things around them. Human ecology is deeply conditioned by beliefs about our nature and destiny—that is, by religion ....more science and more technology are not going to get us the present ecologic crisis until we find a new religion, or rethink our old one. (Horell, 2010, p. 13)

Through eco-theology, humans' positions, relation, and responsibilities of their surroundings according to the religious beliefs are redefined and reinterpreted. God, humans, and natures are the three main components of eco-theology where they relate to each other (Quddus, 2012, p. 318).

Mary Evelyn Tucker and John A, Grim has pioneered the religious forum and environmental, delivered the environmental conservation discourse at national and international levels to promote this issue. Evelyn believed that religion has five perfect recipes to preserve nature they are: Reference, Respect, Restrain, Redistribution, and Responsibility. Vasudha Narayan also stated that there three basic efforts to save the world based on religious beliefs, Text, Temple, and Teacher (Tucker, 2000, p. 12).

Nasr affirmed that modern humans are stuck in anthropocentric beliefs and have lead to ecological catastrophe for years. It is also stated that westerners are worshipping technology and knowledge over spiritualism resulting in irrational and inhumane behaviors (Nasr, 1975, p. 4).

Gardner recommended environmental activist to consider religion as the climate crisis solutions. The roles of religion in the scientific context are codependency of cosmology and ecology values, moral authority, huge followers foundation, significant material resources, and community building capacity.

According to Nasr, religious values and moral pearls of wisdom in ecotheology are vital to sustaining the world's continuity. Nasr emphasized 
Quddus, A. (2020). ECO-PESANTREN AS THE PANACEA FOR GLOBAL CLIMATE CHANGE: LESSONS FROM NURUL HARAMAIN NW LOMBOK ISLAMIC BOARDING SCHOOL INDONESIA. Jurnal Tatsqif, 18 (2), 111-121. https://doi.org/10.20414/jtq.v17i2.2741

Muslims to contribute their thoughts in response to environmental conservations. Muslims are challenged to partake in ecological sustainability within or beyond the concepts and to implement in daily life (Nasr, 1996, p. 12)

Nasr expressed there are two urgent Islamic agenda, First, formulate and promote philosophia perennis of the natural order, religious significance upon the strong bond in life phases. Second, expand and develop ecological awareness based on eco-theology perspectives and enlarge its principle to sharia law.

On August 31, 2011, Tuan Guru Hasanain of Nurul Haramain prized Ramon Magsaysay noble from Philippine. This international noble is regarded as his sustainable effort that has been pioneered since 5 years ago. Tuan Guru Hasanain was chosen because he was concerned for a communitybased approach to boarding school education in Indonesia, creatively promoting the values of gender equality, religious harmony, environmental preservation, individual achievement, and community engagement among young students and their communities. A series of national and international awards have been achieved, including the Ashoka International Award for Master Teacher. Hasanain has made innovation breakthroughs in social issues, pluralism, and gender perspectives in boarding schools. Environmental Licensing Charter from the Regent of West Lombok due to its consistency with forest and water conservation activities. Ma'arif Award from Shafi'i Ma'arif for gender-based education, pluralism, and environmental conservation. Ramon Magsaysay Award for Education, Women Empowerment, Humanism, and the Environment and whose achievement in 2015 was awarded the Republican Change Figure. In addition, Tuan Guru Hasanain became one of 72 outstanding icons selected in the Achievement Festival initiated by the Presidential Work Unit for The Development of Pancasila Ideology (UKP Pancasila) at the Jakarta Convention Center on August 21 and August 22, 2017. Tuan Guru Hasanain's name is 
Quddus, A. (2020). ECO-PESANTREN AS THE PANACEA FOR GLOBAL CLIMATE CHANGE: LESSONS FROM NURUL HARAMAIN NW LOMBOK ISLAMIC BOARDING SCHOOL INDONESIA. Jurnal Tatsqif, 18 (2), 111-121. https://doi.org/10.20414/jtq.v17i2.2741

included in the achievement icon in the category of socio-preneur for his dedication so far (Nurul Haramain NW Boarding School Profile, 2016).

Tuan Guru Hasanain is the founder of Pondok Pesantren Nurul Haramain in Desa Lembuak, West Lombok, NTB established 18 years ago. Annual tree planting has been conducted and shares millions of tree seedlings for free. In the past 10 years, Tuan Guru Hasanain along with his thousand students has restored 56 hectares of bare land in Lombok Island and Sumbawa, including 36 hectares of bare lands he owned in 2003 that he restored in Lembah Madani forest conservation. On top of that, a great number of tree seedlings has emerged in the school, which reached 1 to 1.5 million seedlings per year. They distributed to the community for free (Interview, Yusuf, 2019 August).

Within this context, the Islamic boarding school is considered to bridge the issue and to shed light on solutions in facing climate crisis based on the eco-theology beliefs in Al-Quran and Hadith.

According to Qadir, there are 750 verses or one-eighth of all scripture verses that encourage Muslims to study, ponder regarding this issue. The conservation of nature is not only discussed in fiqh, but also the ushul fiqh especially in the explanation of the main purposes of sharia (maqāsīd alsharī'ah), this is what was then called al-dharrahı̆ al-khamsa (five fundamental bases) which became the foundation of human life. The first person to lay the foundation was Imam al-Gazālī in his book al-Mustafa min ilmi al-ušll which discussed much of the public interest (al-maslahah almursālah). Followed by a cleric named Izuddin ibn Abdussalam who wrote Qawā'id al-Ahkām fì Masālil al-Anam explaining that the decline of sharia was to realize the human serenity in the world and the hereafter. Various substantive rules of sharia concerning the environment can be found in the fiqh books, especially the mu'āmalah branch or business. The themes of the book including turning on vacant land (ihyā' al-mawāt), protected areas (himā), water use for irrigation and food sources (sirb), land granting (himā), land lease (ijārah), maintenance of (nafaqah), the law of hunting and 
Quddus, A. (2020). ECO-PESANTREN AS THE PANACEA FOR GLOBAL CLIMATE CHANGE: LESSONS FROM NURUL HARAMAIN NW LOMBOK ISLAMIC BOARDING SCHOOL INDONESIA. Jurnal Tatsqif, 18 (2), 111-121. https://doi.org/10.20414/itq.v17i2.2741

slaughtering (sayd and dhaba'ih), property (milk and māl), economic transactions (buyu'), peace (sulh), preaching (awqāf) and zakat and taxes. According to Tuan Guru Hasanain, Islam is a religion that pays great attention to sustainable green life. There are many hadiths of the Prophet (pbuh) that advocate the importance of sustainability. According to Tuan Guru Hasanain, should be the agent of change, particularly in environmental issues. Hasanain exemplifies, the Prophet (pbuh) redeemed Salman al-Pharisee's companion by planting dates. As many as 500 palm stems are planted in the desert. He planted 499 palm stems and one left for Umar ibn Khattab. Tuan Guru Hasanain perceived the hadith of the Prophet (s): "There is none amongst the Muslims who plants a tree or sows seeds, and then a bird, or a person or an animal eats from it, but is regarded as a charitable gift for him."

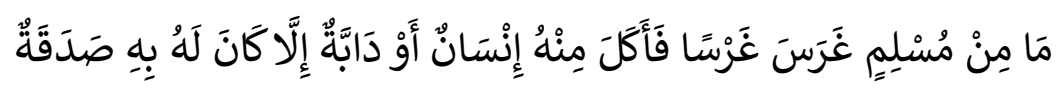

Allah's Messenger ( said, "There is none amongst the Muslims who plants a tree or sows seeds, and then a bird, or a person or an animal eats from it, but is regarded as a charitable gift for him." (Tafsir Ath-Tabari)

Nurul Haramain boarding school has implemented a sustainable living in its daily operation. Besides, restoring the infertile soils, Tuan Guru Hasanain also managed to save the spring and prevent landslides. He also invented an eco-friendly incinerator as well as promoting gender equality in the school where girls are allowed to find their potentials.

Mahagoni woods are located in Dusun Lebah Suren, Dusun Gunung Jae, Dusun Sedau, Dusun Selek Aik, Desa Sedau in Narmada district, West Lombok. Four-wheeled cars are used to go into the wood in the dry season, but it is very hard to pass through in the rainy season because dirt roads become perforated due to eroded flooding. The second location is in Sayong Village, Sekotong Sub-District, $86 \mathrm{~km}$ from Narmada. The location was a mountainous area that was originally occupied only by shrubs, rock soil, $80 \%$ of the ground level was covered by large rocks and medium size. Red clay and black clay mix. Two-wheeled and four-wheeled vehicles only reach the 
villages. As for the forest area, it is reached on foot (Interview, Yusuf, 2019, July).

Alongside forests and bare land, Tuan Guru Hasanain also motivated students to plant trees in public facilities that have parks and land, such as in Lombok International Airport Park (BIL), as well as thousands of trees already grown along the highway. The rapid development of green sustainability and determined people to follow environmental conservation activities, hence this great work certainly costs many expenses and times. Tuan Guru Hasanain initiated the female students to partake in this activity, from planting to seedling process. He empowers his female students to be environmental agents of this modern age. This movement is followed by the establishment of the NTB Women Planting Movement.

At the beginning of planting activities in 2005, Tuan Guru Hasanain involved all components of Pesantren Nurul Haramain NW Narmada, ranging from students, teachers (husband/wife), cottage families, and alumnae. Every day they are invited to go up to gawah (garden) to plant, water, and care for the plants. Tuan Guru Hasanain deliberately involving many people around him. The surrounding community (Suren Bee community) is also actively involved in environmental maintenance. Tuan Guru Hasanain also invited his NGO colleges, such as NGO Santiri and Samanta to train the community about the forest.

\section{CONCLUSION}

It is evident in this study that: Firstly, ecological values are abundant in the Al-Quran and Hadith which is called eco-theology. Secondly, Nurul Haramain NW boarding school has been promoting and endorsing a sustainable lifestyle within and beyond the community based on the Islamic teachings, where the institution acts as the environmental agency. Thirdly, Tuan Guru Hasanain along with his 10 thousand students successfully 
restored infertile soils in Lombok and Sumbawa which were transformed into Lembah Madani forest conservation.

According to the present study there are a few recommendations needed: It is important, first, to take a further implication of promoting ecotheology in the contemporary context; secondly, to raise ecological awareness which is based on eco-theology knowledge and also to expand its application in all level educational institutions; thirdly, to develop an ecological curriculum in all level educational institutions.

\section{REFERENCES}

Alieansi Manado. (2009). Menggusur Nelayan Menenggelamkan keadilan Iklim,; Sisi gelap Bahaya WOC dan CTI. Alieansi Manado.

Arikunto, S. (2010). Prosedur Penelitian: Suatu Pendekatan Praktik. Jakarta: Rineka Cipta.

Bahri, Sy. (2018). Pesantren and the Development of Living Environment: The Study Concept of Eco-Pesantren In Pondok Pesantren An-Nur Ha Rambigundam Jember. International Journal of Management and Administrative Sciences 5 (10).

Deperteman Agama RI-Direktorat Jenderal Kelembagaan Agama Islam. (2003, Pondok Pesantren dan Madrasah Diniyah; Pertumbuhan dan Perkembangannya. Jakarta: Deperteman Agama RI.

Foltz, R., Denny, C. F., \& Baharuddin, A. (2003). Islam and Ecology: A Bestowed Trust. Harvard: Harvard University Press

Gadner, G. (2002). Invoking the Spirit; Religion and Spirituality in the Quest for A Sustainable World. Washington, DC: Worldwatch Institute.

Horell, D. G. (2010). Greening Paul: Rereading The Apostle In A Time of Ecological Crisis. Texas: Baylor University Press.

Horikoshi, H. (1987). Kiyai dan Perubahan Sosial. Jakarta: P3M.

Kodra, H. S. A. Kapasitas Pengelolaan SDA dan Lingkungan Hidup", Diktat Seminar Kajian Islam Komprehensif. Jakarta: Pascasarjana UIN Jakarta. 
Kodra, H. S. A., \& Syaukani HR. (2004). Bumi Makin Panas Banjir Makin Luas. Bandung: Yayasan Nuansa Cendikia.

Mangunjaya, F.M., Heriyanto, H., \& Gholami, R. (2007). Menanam Sebelum Kiamat. Jakarta: Yayasan Obor Indonesia.

Narayan, V. (2000). Water, Wood and Wisdom; Hindu Ecological Perspectives dalam Harold Coward and Daniel McGuire, eds. Vision of The Earth. New York: State University of New York Press.

Nasr, S. H. (1975). Islam and Plight of Modern Man. London and New York: Longman.

. (1988). Man and Nature; The Spiritual Crisis of Modern Man.

. (1989). Knowledge and The Sacred. Albany: State University of New York Press.

. (1996). Religion and the Order of Nature. New York: Oxford Univbersity Press.

Qadir, C.A. (1988). Philosophy and Science in the Islamic World. London: Routledge.

Quddus, A. (2012). Ecotheology Islam; Teologi Konstruktif Atasi Krisis Lingkungan. Ulumuna; Jurnal Studi Keislaman 16 (2).

. (2015). Menggagas Fiqh al-Bī’ah sebagai Basis Etis-Praktis Konservasi Alam. Ulumuna 19 (1).

Sulaiman, M. M. (1998). Dinamika Masyarakat Transisi. Yokyakarta: Pustaka Pelajar.

Tan, C. (2012). Islamic Education and Indoctrination: The Case in Indonesia. London: Routledge.

Tucker, M. E. (2000). velyn Hinduism and Ecology. Cambrigde: Harvard University Press. 